\title{
Ectoparasites of Sheep and Goats in North-West Amhara Regional State, Ethiopia
}

Sisay Amare ${ }^{1}$ *, Yilkal Asfaw ${ }^{2}$ and Yacob Hailu Tolossa ${ }^{2}$

${ }^{1}$ Wollo University, School of Veterinary Medicine, P.O. Box 1145, Dessie, Ethiopia

${ }^{2}$ Addis Ababa University College of Veterinary Medicine and Agriculture, P.O.Box 34, Debre

Zeit

* Corresponding author: Sisay Amare e-mail: gsisayamare@yahoo.com

\section{Abstract}

A cross-sectional study on ectoparasites of sheep $(n=738)$ and goats $(n=492)$ was conducted in Northwestern Amhara Regional State of Ethiopia from October 2009 to April 2010 to determine the prevalence of major ectoparasites of sheep and goats and the associated risk factors. Out of the clinically examined animals, 331(44.9\%) sheep and 214 (43.5\%) goats were infested with one or more ectoparasites. Ectoparasites identified in sheep were Damalinia ovis $(30.9 \%)$, Mellophagus ovinus (10.8\%), ticks (3.9\%), Linognathus species (3.1\%) and flea (1.1\%). Among goats, Linognathus species, ticks, flea and demodectic mange were identified with respective prevalence of $27 \%, 17.7 \%, 2.6 \%$ and $2.2 \%$. Sheep in midland were 3.7 and 2.3 times more at risk for Damalinia ovis infestation than sheep in highland and lowland, respectively and also goats in midland were 1.8 times at risk for Linognathus species than lowland sheep $(\mathrm{P}<0.05)$. Sheep poor in body condition were 1.9 times more at risk for Damalinia ovis than good body condition sheep and goats poor in body condition were 3.5 times more at risk for Linognathus species than good body condition goats $(\mathrm{P}<0.05)$. Age and wool length of sheep were important predictors for the presences of Mellophagus ovinus on highland sheep. The prevalence of Mellophagus ovinus was significantly higher in young and long wool sheep than in adult and short wool sheep $(\mathrm{P}<0.05)$. The observed overall prevalence is generally high which may result in enormous economic losses through decreased production and productivity, damages to the skin and deaths of the animal which requires an immediate attention and professional intervention.

Key words: Ectoparasites, Ethiopia, Goat, Prevalence, Risk factors, Sheep.

http://dx.doi.org/10.4314/evj.v17i1.5 


\section{Introduction}

In Ethiopia sheep and goats are important contributors to the economy; providing $25 \%$ of meat consumption, about half of the domestic wool requirements and $92 \%$ of the value of semi-processed skin and hide export trade. They also play an important role by providing export commodities such as live animals, meat and skins to earn foreign exchange to the country. Sheep and goat skins rank among the largest export commodities (Kleemann, 2008; Alemu Yami and Merkel, 2009). Ethiopian small ruminant skins, especially sheep skins traditionally have a very good reputation for quality in the world leather market due to their fine grain and compact structure. Though Ethiopia has very good potential to produce substantial quantities of skins, the quality of skins supplied is deteriorating from time to time. This has resulted in an ever increasing number of complaints about the quality of skins available to local tanners and the export market. The problem has adversely affected all aspects of the industry including the income derived from exports. Hides and skins were accounting for $14-16 \%$ of the country's total foreign trade revenues several years ago, this value has actually dropped to $9-10 \%$ due to a shortage of hides and skins of good quality (Kleemann, 2008).

Skin diseases caused by ectoparasites of small ruminants (lice, ked, mange mites and ticks) are among the major factors for shortage of hides and skins of good quality. Ectoparasites of small ruminants cause mortality, decreased production and reproduction of small ruminants and also they cause serious skin defects that end up with down grading of quality and rejection of skin (Kassa Bayu, 2005; Tefera Sertse and Abebe Wossene, 2007a, Mulugeta Yebegashet et al., 2010).

Parasitic mites, lice and keds are considered as a potential threats and pose a serious economic problem to the development of sheep and goats production and the tanning industry in the country and need control intervention (Tefera Sertse and Abebe Wossene, 2007b; Mulugeta Yebegashet et al., 2010). Taking these effects into consideration regions which are most affected (Afar, Tigray and Amhara Regions) have launched control measures to major ectoparasites of small ruminants (MoARD, 2005) and implemented for the last three years (Kleemann, 2008).

Despite the ongoing ectoparasites control activity, problem of ectoparasitic skin diseases of small ruminants is still active and serious in northern parts of Ethiopia. For instance, in Tigray Regional state, after the realization of the control program an overall ectoparasite prevalence of $55.5 \%$ in sheep and $58 \%$ in goats were reported (Mulugeta Yebegashet et al., 2010). Similarly, in eastern Amhara region 
by Tefera Sertse and Abebe Wossene (2007a) $50.5 \%$ in sheep and $56.4 \%$ in goats before the control program was launched. Therefore, the objectives of this study are to determine the current prevalence of major ectoparasites of sheep and goats after extensive implementation of control program and assess the potential risk factors associated with prevalence of ectoparasites.

\section{Materials and Methods}

Study area and study animal

The study on small ruminant ectoparasites causing skin diseases was conducted in three districts (Metema from north Gonder, Bahir Dar from west Gojam and Farta from south Gonder zones) representing lowland, midland and highland agroclimatic zones, respectively, in western Amhara National Regional State, northwestern Ethiopia. The selected districts are about 923, 563 and $663 \mathrm{kms}$ far from Addis Ababa, respectively. The geographical locations of study areas are 12,58,00 north and 36,11,00 east for Metema, 11,33,00 north and 37,22,00 east for Bahir-Dar and 11,51,00 north and 38,00,00 east for Farta. Metema district has a common boundary with The Sudan. The production system is mixed crop livestock in Bahir Dar and Farta and Agro pastoral in Metema. Livestock are managed under extensive system in all of the three districts. Small ruminants in the areas are indigenous breeds. In Metema they are managed separately from other livestock while in the other two districts they are managed mixed with other livestock.

Study design, sampling methods and sample size determination

A cross-sectional study on the prevalence of major ectoparasites (mites, lice, sheep keds, flea and ticks) of small ruminants was designed. The association of host and agro-climate (environment) related risk factors (explanatory variables) with the presence of the ectoparasites (response variables) were investigated. The host risk factors considered were age, body condition, wool length and species while highland, midland and lowland were environment related risk factors. From each district four peasant associations (PA) were identified conveniently for their accessibility and purposively to represent the different agro climatic zones (highland, midland and lowland). Sheep and goats from each PA were sampled randomly from populations that were collected on the communal grazing areas.

The sample size of animals to be included in the study was determined following 
the formula given by Thursfield (2005). Based on this formula and taking estimated prevalence of $20 \%$ for each ectoparasite in each agro-climate, desired absolute precision (accepted error) 5\% and confidence level of $95 \%$ the minimum sample size required were 246 sheep and 246 goats in each district. Goats were not considered in highlands because of their low population and inaccessibility. A total of 1230 small ruminants (738 sheep and 492 goats) were included in the study.

Clinical examination, sample collection and laboratory examination

Before clinical examination for ectoparasites related risk factors such as body condition score, age, sex and hairiness of each sampled animal were recorded. Body condition scoring was done by modifying systems utilized by Girma Abebe and Alemu Yami (2008) and by Steel (1996) for sheep and goats, respectively. Based on these poor body condition score was given to sheep and goats having body condition score of 0 and 1 , while good body condition score was given to sheep and goats having body condition score of 2 to 5. Age categorization into young (lamb/kid) and adult was determined as described by Girma Abebe and Alemu Yami (2008) for sheep and goats. Accordingly sheep and goats up to one year were categorized as young and the rest as adult. The study animals were examined clinically for the presence of ectoparasites and/or skin lesions. Sheep and goats found infested by parasites were considered positive. The sites of infestation on the animal body were recorded.

Ectoparasites and their larvae unidentified during clinical examination, and skin scrapings of mange like lesions from clinically suspected animals were collected in clean universal bottles, for detailed laboratory examination. Skin scrapping for mange mites was collected and processed in the laboratory according to the method described by Chauhan et al., (2006). Ticks and lice were collected by hand from their attachment site, put into containers and preserved in $70 \%$ alcohol (Urqhart et al., 1996). The collected samples were examined by Stereomicroscope and identification was done based on their morphological features given by OkelleOnen et al, (1999) and Walker et al., (2003) for ticks and Urquhart et al., (1996) and Wall and Shearer (1997) for lice and mites. The samples were processed in Bahir-Dar Regional Veterinary Laboratory.

Three hypothesized risk factors (agro climate, age and body condition of sheep and goats) were considered for analysis to determine risk factors that are significantly associated with presence of ectoparasites in sheep and goats. 
Data management and analysis

The significance of association of potential risk factors (explanatory variables) to the presence of ectoparasites was determined by binary logistic regression using SPSS-15 for windows software. The explanatory variables considered were separately analyzed to see their association with the outcome status of ectoparasite infestation of sheep and goat. Finally to identify important risk factors (explanatory variables) and to avoid a large type I error either forward or backward likelihood ratio method of variable selection was employed using Hosmer-Lemeshow statistics. For all tests P-value less than 0.05 were considered to be statistically significant.

\section{Results}

Investigation of 738 sheep and 492 goats for ectoparasite infestations was conducted to determine the prevalence of infestation. From the study, the overall prevalence of ectoparasites in sheep and goats were $44.9 \%$ and $43.5 \%$, respectively. On sheep, infestation with D. ovis, M. ovinus, ticks, Linognathus species and flea were identified with respective prevalence of $30.9 \%, 10.8 \%, 3.9 \%$, $3.1 \%$ and $1.1 \%$.The ectoparasites identified on goats were Linognathus species $(27 \%)$, ticks $(17.7 \%)$, flea $(2.6 \%)$ and demodectic mange $(2.2 \%)$. Both on sheep and goats mixed infestation by two or more ectoparasites were recorded with prevalence of $5.0 \%$ and $6.9 \%$, in order (Table 1). Tick species of A. variegatum, $A$. lepidum and $B$. decoloratus were collected from sheep and $R$. preatextatus, $R$. sanguineus, $B$. decoloratus, A. variegatum, $H$. marginatum. marginatum, $H$. maginatum, rufipes and $H$. impeltatum were found in goats.

The common sites of $D$. ovis infestation on sheep were the sides, the back, the neck, the rump and the shoulder with decreasing proportion. The major tick attachment sites in sheep were on legs, head/ear, belly/sternum and other sites in decreasing order; while in goats $91.8 \%$ were found to attach on head/ear and the rest on the other sites of the body (leg, belly and scrotum). 
Table 1: The prevalence of ectoparasites identified on sheep and goats

\begin{tabular}{lcccccc}
\hline Ectoparasites & \multicolumn{3}{c}{ Sheep $(\mathrm{n}=738)$} & \multicolumn{3}{c}{ Goat $(\mathrm{n}=492)$} \\
\cline { 2 - 7 } & $\begin{array}{c}\text { Total } \\
\text { positive }\end{array}$ & Prevalence & $95 \%$ CI & $\begin{array}{c}\text { Total } \\
\text { positive }\end{array}$ & Prevalence & $95 \%$ CI \\
\hline D. ovis & 228 & 30.9 & $26.0-34.2$ & 0 & 0 & 0 \\
D. caprae & 0 & 0 & 0 & 4 & 0.8 & nd \\
M. ovinus & 80 & 10.8 & $8.6-13.0$ & 0 & 0 & 0 \\
Linognathus species & 23 & 3.1 & $1.9-4.4$ & 133 & 27.0 & $25.0-29.0$ \\
Ticks & 29 & 3.9 & $2.5-5.3$ & 87 & 17.7 & $14.3-21.1$ \\
Demodex & 0 & 0 & 0 & 11 & 2.2 & $0.9-3.5$ \\
Flea & 8 & 1.1 & $0.4-1.9$ & 13 & 2.6 & $1.2-4.0$ \\
Mixed infestations & 37 & 5.0 & $3.4-6.6$ & 34 & 6.9 & $4.7-9.1$ \\
Overall & 331 & 44.9 & $41.3-48.5$ & 214 & 43.5 & $39.1-47.9$ \\
& & & & & &
\end{tabular}

nd refers to not determined

Among sheep, agro climate and body condition were significantly associated with prevalence of $D$. ovis and Linognathus species. The prevalence of $D$. ovis in midland sheep (48.4\%) was significantly higher than the prevalence on both lowland (24.8\%) and highland sheep (19.5\%) (OR=2.3 and 3.7, respectively; $\mathrm{P}=0.000$ ). The presence of $D$. ovis in lowland sheep was also 1.6 times compared to the highland sheep which was statistically significant $(\mathrm{P}=0.04)$. The prevalence of Linognathus species in midland sheep $(8.1 \%)$ was significantly higher than that in lowland sheep (1.2\%). The prevalence of D. ovis and Linognathus species in sheep were significantly higher in poor than in good body condition sheep $(\mathrm{OR}=1.9, \mathrm{P}=0.000$ for $D$. ovis and $\mathrm{OR}=3.5, \mathrm{P}=0.03$ for Linognathus $)$. For tick infestation of sheep it was only age which was found significant predictor of infestation (Table 2).

On goats, agro-climate and body condition of the animal were significantly associated with the prevalence of Linognathus species infestation. The prevalence was 1.8 times higher in midland than lowland goats and 3.5 times higher in poor than in good body condition goats $(\mathrm{P}<0.05)$ (Table 3$)$. The predicted risk factors were also considered for analysis to determine risk factors that are significantly associated with prevalence of tick infestation in goats and it was only agro climate that was significantly associated with prevalence of tick infestation. The prevalence of tick in lowland goats $(21.1 \%)$ was significantly higher than the prevalence in midland goats $(14.2 \%)(\mathrm{OR}=1.7 ; \mathrm{P}=0.024)$. This study also indicated that agro climate could be risk factor for the presence of flea infestation on goats. The presence of flea infestation on midland goats was 11.8 times higher $\mathrm{P}=0.02$ ) compared to the lowland goats (Table 3). 
Sisay Amare, et al.

Table 2: Logistic regression analysis result for association of potential risk factors with the prevalence of ectoparasites in sheep

\begin{tabular}{|c|c|c|c|c|c|c|}
\hline $\begin{array}{l}\text { Major } \\
\text { ectoparasites }\end{array}$ & Risk factors & $\begin{array}{l}\begin{array}{l}\text { Risk factor } \\
\text { category }\end{array} \\
\end{array}$ & $\begin{array}{c}\text { Prevalence } \\
(\%)\end{array}$ & P-value & OR & $\begin{array}{c}55 \% \\
\text { CI for OR } \\
\end{array}$ \\
\hline \multirow[t]{8}{*}{ D. ovis } & \multirow{4}{*}{$\begin{array}{l}\text { Agro- } \\
\text { climate }\end{array}$} & Highland $(\mathrm{n}=246)$ & 19.5 & & & \\
\hline & & Lowland $(n=246) *$ & 24.8 & 0.04 & 1.6 & $1.0-2.5$ \\
\hline & & Midland $(\mathrm{n}=246) *$ & 48.4 & 0.000 & 3.7 & $2.4-5.5$ \\
\hline & & Midland $(\mathrm{n}=246) * *$ & 48.4 & 0.000 & 2.3 & $1.5-3.4$ \\
\hline & \multirow[t]{2}{*}{ BCS } & Poor $(n=362)$ & 40.1 & \multirow[t]{2}{*}{0.000} & \multirow[t]{2}{*}{1.9} & \multirow[t]{2}{*}{$1.4-2.8$} \\
\hline & & Good $(n=376)$ & 22.1 & & & \\
\hline & \multirow[t]{2}{*}{ Age } & Young (n=297) & 36.7 & \multirow[t]{2}{*}{0.119} & \multirow[t]{2}{*}{1.3} & \multirow[t]{2}{*}{$0.9-1.8$} \\
\hline & & Adult $(n=441)$ & 27.0 & & & \\
\hline \multirow{7}{*}{$\begin{array}{l}\text { Linognatus } \\
\text { species }\end{array}$} & \multirow{3}{*}{$\begin{array}{l}\text { Agro- } \\
\text { climate }\end{array}$} & Highland $(n=246)$ & 1.2 & & & \\
\hline & & Lowland $(\mathrm{n}=246)$ & 0.0 & - & - & - \\
\hline & & Midland $(n=246) *$ & 8.1 & 0.003 & 6.3 & $1.8-21.6$ \\
\hline & \multirow[t]{2}{*}{$\mathrm{BCS}$} & Poor (n=362) & 5.2 & \multirow[t]{2}{*}{0.03} & \multirow[t]{2}{*}{3.5} & \multirow[t]{2}{*}{$1.1-10.6$} \\
\hline & & Good $(n=376)$ & 1.1 & & & \\
\hline & \multirow[t]{2}{*}{ Age } & Young $(n=297)$ & 3.0 & \multirow[t]{2}{*}{0.297} & \multirow[t]{2}{*}{0.6} & \multirow[t]{2}{*}{$0.3-1.5$} \\
\hline & & Adult $(\mathrm{n}=441)$ & 3.2 & & & \\
\hline \multirow[t]{7}{*}{ Ticks } & \multirow{3}{*}{$\begin{array}{l}\text { Agro- } \\
\text { climate }\end{array}$} & Highland $(n=246)$ & 0.0 & - & - & - \\
\hline & & Lowland (n=246) & 8.1 & & & \\
\hline & & Midland $(\mathrm{n}=246) * *$ & 3.7 & 0.124 & 0.5 & $0.2-1.2$ \\
\hline & \multirow[t]{2}{*}{$\mathrm{BCS}$} & Poor $(n=362)$ & 2.8 & \multirow[t]{2}{*}{0.807} & \multirow[t]{2}{*}{0.9} & \multirow[t]{2}{*}{$0.4-2.1$} \\
\hline & & Good $(n=376)$ & 5.1 & & & \\
\hline & \multirow[t]{2}{*}{ Age } & Young (n=297) & 1.0 & & & \\
\hline & & Adult $(\mathrm{n}=441)$ & 5.9 & 0.008 & 5.3 & $1.5-18.0$ \\
\hline
\end{tabular}

* Highland reference

** Lowland reference

Table 3: Logistic regression analysis result for association of potential risk factors with the prevalence of ectoparasites in goats

\begin{tabular}{|c|c|c|c|c|c|c|c|c|c|c|}
\hline \multirow{3}{*}{ Risk factors } & \multirow{3}{*}{$\begin{array}{l}\text { Category of risk } \\
\text { factors }\end{array}$} & \multicolumn{9}{|c|}{ Ectoparasites } \\
\hline & & \multicolumn{3}{|c|}{ Linognathus } & \multicolumn{3}{|c|}{ Ticks } & \multicolumn{3}{|c|}{ Flea } \\
\hline & & $\overbrace{0}^{*}$ & 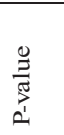 & 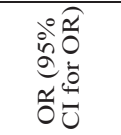 & $\overbrace{0}^{*}$ & $\begin{array}{l}\frac{0}{\pi} \\
\frac{\pi}{\pi} \\
\frac{1}{2}\end{array}$ & 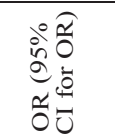 & $\overbrace{0}^{*}$ & 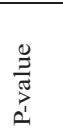 & 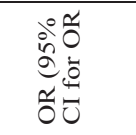 \\
\hline \multirow[t]{2}{*}{ Agro-climate } & Midland(n=246) & 34.6 & 0.007 & $1.8(1.2-2.8)$ & 14.2 & & & 4.9 & 0.019 & $11.8(1.5-93.0)$ \\
\hline & Lowland(n=246) & 19.5 & & & 21.1 & 0.024 & $1.7(1.1-2.8)$ & 0.4 & & \\
\hline \multirow[t]{2}{*}{ BCS } & Poor $(n=181)$ & 44.2 & 0.000 & $3.5(2.3-5.3)$ & 19.9 & 0.15 & $1.4(0.9-2.3)$ & 3.9 & 0.528 & $1.4(0.5-4.4)$ \\
\hline & Good (n=311) & 17.0 & & & 16.4 & & & 1.9 & & \\
\hline \multirow[t]{2}{*}{ Age } & Young $(\mathrm{n}=242)$ & 31.0 & 0.064 & $1.5(0.9-2.3)$ & 15.7 & 0.225 & $0.7(0.5-1.2)$ & 3.3 & 0.363 & $1.7(0.5-5.3)$ \\
\hline & Adult (n=250) & 23.3 & & & 19.6 & & & 2.0 & & \\
\hline
\end{tabular}

*=prevalence 
In this study, M. ovinus was found to infest only highland sheep with a prevalence of $32.5 \%$. Analysis of hypothesized risk factors (wool length, age and BCS) with the presence of $M$. ovinus showed wool length and age to be potential risk factors. The prevalence in long wool sheep was significantly higher than the prevalence in short wool sheep $(\mathrm{OR}=5.4$ and $\mathrm{P}=0.000)$. The presence of $M$. ovinus infestation in young sheep was 4.1 times compared to the adult sheep. (Table 4).

Table 4: Prevalence of M. ovinus on highland sheep based on risk factors

\begin{tabular}{llllll}
\hline Risk factors & & prevalence(\%) & P-value & OR & $95 \%$ CI for OR \\
& & & & & \\
\hline \multirow{2}{*}{ Wool length } & Short wool $(\mathrm{n}=112)$ & 14.3 & & 1 & \\
& Long wool (n=134) & 47.8 & 0.000 & 5.4 & $2.7-10.5$ \\
Age & Adult (n=139) & 19.4 & & 1 & \\
& Young (n=107) & 49.5 & 0.000 & 4.1 & $2.1-7.5$ \\
\multirow{3}{*}{ BCS } & Good (n=123) & 24.4 & & 1 & \\
& Poor $(\mathrm{n}=123)$ & 40.7 & 0.735 & 1.1 & $0.6-2.1$ \\
\hline
\end{tabular}

\section{Discussion}

In this study the overall prevalence of ectoparasites found both for sheep and goats were high, but it was lower than the overall ectoparasites prevalence previously reported both in sheep and goats in the country by Tefera Sertse and Abebe Wossene (2007a); Mulugeta Yebegashet et al (2010) and Asnake Fekade (2008). The relatively low overall ectoparasites prevalence found in this study may be due to the effect of the ongoing ectoparasites control program in the region.

Lice infestations were the most prevalent ectoparasites recorded both in sheep and goats. The prevalence of $D$. ovis infestation in sheep in this study was higher than that was reported in different parts of Ethiopia (Yacob Hailu et al., 2008 and Mulugeta Yebegashet et al., 2010). But it was relatively lower than the report of 38.5\% prevalence in Eastern Amhara (Tefera Sertse and Abebe Wossene, 2007a). The prevalence of Linognthus species in goats observed in this study was higher than that was reported by scholars in Ethiopia (Numery Abdulhamid, 2001). On the contrary, it was almost similar to that was reported by Tefera Sertse and Abebe Wossene (2007a) and Mulugeta Yebegashet et al., (2010).

The lice infestation prevalence differences observed between the different studies may be partly attributed to differences in agro climate and season of study since there is strong seasonal cycle in louse numbers (James et al., 1998). The 
management and health care of sheep and goats in the study areas will also be another factor since lice infestation is an indication for some other underlying problems such as malnutrition and chronic diseases (Kettle, 1995; Kaufmann, 1996; Wall and Shearer, 1997). Furthermore, the sensitivity of the diagnostic method used and spatial distribution of lice on sheep may be another factor (James et al., 2002b). In addition to this, rubbing is a powerful indicator of infestation and choosing a sheep with rubbed fleece greatly increases the likelihood of detection (James et al., 2007) and hence, the prevalence of infestation.

M. ovinus was the second most prevalent ectoparasites observed in sheep with an overall prevalence of $10.8 \%$. This figure was nearly similar to that was reported for eastern Amhara (12.5\%) (Tefera Sertse and Abebe Wossene, 2007a). However, it was lower than that were reported by Mulugeta Yebegashet et al., (2010) for Tigray $19.1 \%$. The difference observed may be due to the agro-climate difference and method of study. The parasite establish itself in temperate countries and in the cooler highlands of tropics but is absent from the hot, humid tropics and heavy infestation occurs in cold wet seasons (Radostitis et al., 1994). In line with this in the present study the parasite was observed only in highland sheep.

In this study, mange caused by demodex was registered with $4.4 \%$ prevalence only in goats. According to ABoA (2000), Metema district was one of the severely mange affected areas. But in this study except demodectic mange there were no other causes of mange in small ruminants all over the study areas. This may be due to the effect of the three years ectoparasite control activity practiced in the region.

From the predictor variables considered for association with the presence of lice on sheep and goats, only agro climate and body condition were significantly associated with presence of D. ovis in sheep and Linognathus species both in sheep and goats. Lice breed within narrow temperature range; when temperature is cooler than optimum, eggs do not develop while hotter temperature prevent egg laying and kill the lice. Optimum temperature for D. ovis is between $37^{\circ} \mathrm{C}$ and $39^{\circ} \mathrm{C}$. Environmental conditions which subject lice to temperatures outside of this range reduce louse reproduction (Kettle, 1995; Radostitis et al., 1994). These are facts explaining the present finding that the presence of $D$. ovis in midland sheep was significantly higher than both in lowland and highland sheep. The same fact will also explain the observed significant association of agro-climate with presence of Linognathus spp. both on sheep and goats.

Furthermore, Shearing directly removes $30-50 \%$ of lice and many more die subsequently because of exposure to environmental influences and if the fleece 
remains saturated with moisture, as can occur in fleece after heavy rain, for more than six hours many nymphs and adults can drown and hatching of eggs is inhibited (Kettle, 1995; Urqhuart et al., 1996). In line with this, the authors observed that the highland farmers practice shearing and dipping sheep in water as best treatment for $M$. ovinus. Exposure of the lice to environmental influences (temperature and moisture) through such practices may partially explain the lower prevalence of $D$. ovis in highland sheep than both midland and lowland.

Lice infestation both in sheep and goats were significantly higher in poor than in good body condition sheep and goats. This could be due to lowered immune response as a predisposing factor and/or the poor body condition could be the result of chronic ectoparasite infestation (James et al. 2002a).

In this study, significant association was observed between agro-climate and the presence of tick infestation in goats. The odds of tick infestation on lowland goats were 1.74 times compared to midland goats. This may be partially due to the vegetation cover that exists in Metema district (lowland) which controls the moisture content of the environment which is important factor for the survival of ticks (Morel, 1989; Urquahrt et al., 1996).

The significant association observed between wool length and presence of $M$. ovinus on sheep could be directly related to the biology of the M. ovinus and sheep management practices in the area. Long wool is favourable for the development of different stages of M. ovinus. At shearing (which is also frequently practiced in the study area) $80-90 \%$ of adult and almost all pupal cases will be removed, and the combination of hot condition and a short fleece kills many of the remaining $M$. ovinus (Kettle, 1995). M. ovinus are blood sucking parasites and heavy infestations may cause severe anaemia, which can weaken the animal and make it more susceptible to other diseases. The excreta can stain the wool and downgrade the fleece. They also cause skin irritation, which result in animal biting and rubbing with resultant damage to the fleece and development of vertical ridging on the skin called cockle that downgrade the skin quality (Urquhart et al., 1996; Bates, 2000; Talley, 2007).

The study revealed that ectoparasites of small ruminants were widely distributed and prevalent in all agro-ecological zones and in all age groups of small ruminants in the study area. The observed overall prevalence is generally high which will result in high economic losses through decreased production and productivity, deaths of the animal and damages of the skin demanding an immediate attention and professional intervention. 


\section{Acknowledgments}

The authors are grateful to Amhara Regional State Agriculture and Rural Development Bureau and College of Veterinary Medicine and Agriculture of Addis Ababa University for the financial support and Bahir-Dar Regional Veterinary Laboratory staff members for the technical support.

\section{References}

Abdulhamid, N., 2001. Prevalence and Effect of Ectoparasites in Goats in Fresh Pelts and Assessment of Wet Blue Skin Defects at Kombolcha Tannery. DVM thesis, Addis Ababa University, Debre Zeit, Ethiopia.

Abebe, G. and Yami, A., 2008. Management of sheep and goats. In: Alemu, Y. and Merkel, R. C. (eds.) Sheep and Goat Production Hand Book for Ethiopia. Ethiopia sheep and goat production program (ESGPIP), PP. 21-32.

Amhara Bureau of Agriculture, ABoA, 2000. Project proposal on the control campaign against mange, lice, and, keds in sheep and goats in Amhara National Regional State, Bahir Dar, Ethiopia.

Bates, P., 2000. Ectoparasites: In Martin, W. B and Atiken, I. D. (eds.) Disease of sheep. $3^{\text {rd }}$ edition, Blackwell science, London, PP.286-296.

Bayu, K., 2005. Country paper Ethiopia. Proceedings of Regional Workshop on preslaughter defects of hides/skins and intervention options in East Africa: Harnessing the Leather Industry to Benefit the Poor, April, 18-20 Addis Ababa, Ethiopia, PP. 71 84.

Chauhan, R.S., and Agarwal, D.K., 2006. Textbook of veterinary clinical and laboratory diagnosis. $2^{\text {th }}$ Edition, Jaypee Brothers Medical publishers, New Delhi, PP. 189-191.

Fekade, A., 2008. Major ectoparasitic skin diseases of small ruminants in three selected agro ecological districts of southern Ethiopia, MSc thesis, Addis Ababa University, Faculty of Veterinary Medicine, Debre Zeit.

Hailu,Y., Tefera, Y. and Ayana, D., 2008. Ectoparasite prevalences in sheep and in goats in and around Wolayta Soddo, Southern Ethiopia. Revue. Méd. Vet., 159, 450-454.

James, P.J., Bartholomaeus, F.W and Karlsson, L.J.E., 2007. Temporal relationship between infestation with lice (Bovicola ovis Schrank) and the development of pruritic behaviour and fleece derangement in sheep. Vet. Parasitol., 149, 25 1-257.

James, P.J., Carmichael, I.H., Pfeffer, A., Martin, R.R. and O'Callaghan, M.G., 2002 a. Variation among Merino sheep in susceptibility to lice (Bovicola ovis) and association with susceptibility to trichostrongylid gastro-intestinal parasites. Vet. Parasitol., 103, 355-365. 
James, P.J., Garrett, J.A. and Moon, R.D., 2002b. Sensitivity of two-stage sampling to detect sheep biting lice (Bovicola ovis) in infested flocks. Vet. Parasitol., 103, 157-166.

James, P J., Moon, R.D. and Brown, D.R., 1998. Seasonal dynamics and variation among sheep in densities of the sheep biting louse, Bovicola ovis. Int. J. Parasitol,. 28, 283 292.

Kaufmann, J., 1996. Parasitic infections of domestic animals: A diagnostic manual. $1^{\text {st }}$ edition Birkhauser Verlag, Berlin. PP. 188-196.

Kettle, D.S., 1995. Medical and Veterinary Entomology. $2^{\text {nd }}$ Edition, Wallingford, Oxon, UK, CAB International, Cambridge, PP. 315-458.

KLeemann, G., 2008. Report on: Consultancy and proposal for the national ectoparasite control program: Report for GTZ-Engineering Capacity Building Program (ECBP) private sector development component and Ministry of Agriculture and Rural Development Ethiopia; Wiesbaden, Germany, September 23, 2008.

Ministry of Agriculture and Rural Development, MoARD, 2005. Mange, Lice and Sheep Ked control project in Amhara, Tigray and Afar regions, MoARD, Animal Health Department, Addis Ababa, Ethiopia.

Morel, P., 1989. Tick born diseases of livestock in A frica. In: Manual of Tropical Veterinary Parasitology, PP. 303-459.

Okello-onen, J., Hassan, S.M. and Essuman, S., 1999. Taxonomy of African Ticks: An Identifcation Manual. ICIPE Science Press, Nairobi, PP. 1-124.

Radostits, O.M., Blood, D.C. and Gay, C.C., 1994. Veterinary Medicine: A Text Book of the Disease of Cattle, Sheep, Pigs, Goats and Horses. $8^{\text {th }}$ Edition, Bailliere Tindall, Lond on, PP. 1280-1308.

Sertse, T. and Wessene, A., 2007a. A study on ectoparasites of sheep and goats in eastern part of Amhara Region, northeast Ethiopia. Small Rumin. Res., 69, 62-67.

Sertse, T. and Wossene, A., 2007b. Effect of ectoparasites on quality of pickled skins and their impact on the tanning industry in Amhara Regional State, Ethiopia. Small Rumin. Res., 69, 55-61.

Talley, J., 2007. External parasites of goats. In: Proc. 22nd Ann. Goat Field Day, Langston University, Langston, OK, PP. 76-80.

Thrusfield, M., 2005. Veterinary Epidemiology. $3^{\text {rd }}$ Edition, Blackwell Science Ltd., UK, PP. 229-245. 
Urquhart, G.M., Armour, J., Duncan, J.L., Dunn, A.M. and Jennings, F.M., 1996. Veterinary Parasitology. $2^{\text {nd }}$ Edition, Blackwell Science, London, PP.141-205.

Walker, A.R., Bouattour, A., Camicas, J., Estrada-pena, A., Horak, I.J., Latif, A.A., et al., 2003. Ticks of Domestic Animals in A frica: A guide to Identification of Species. Bioscience Reports, The Netherlands, PP. 1-221.

Wall, R. and Shearer, D., 1997. Veterinary Entomology. $1^{\text {st }}$ Edition, Champian and Hall, London, PP. 1-438.

Yami, A. and Merkel, R.C., 2009. Ethiopia Sheep and Goat Productivity Improvement Program (ESGPIP), technical bulletin no.19, PP. 1-14.

Yebegashet, M., Hailu Y., and Ashenafi, H., 2010. Ectoparasites of small ruminants in three selected agro-ecological sites of Tigray Region, Ethiopia. Trop. Anim. Health Prod., 42, 1219-1224. 